\title{
Long-term landscape development of the Coloradofjella plateau, central Spitsbergen, Svalbard
}

\author{
Jakob Fjellanger \& Leif Sørbel
}

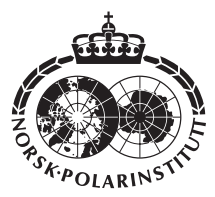

The development and age of the present geomorphology and superficial material of the Coloradofjella plateau, Spitsbergen, have been investigated through field surveying and laboratory sediment analyses. The focus was specifically on the role of glacial erosion and periglacial processes. The summit plain is deeply incised with large V-shaped valleys. Extensive networks of ice wedge polygons indicate that the fine-grained regolith is at least a few metres thick. An abundance of coarse-grained gabbroid erratics, clearly derived from sources further to the east, are distributed over parts of the summit plain. A vertical-walled dolerite dyke protruding up to $4 \mathrm{~m}$ above the adjacent surface shows no sign of glacial erosion. Our findings confirm that the present bedrock geomorphology and regolith in the summit plain survived at least the Late Weichselian glaciation. This is best explained by the ice sheet having been cold-based throughout its existence on the summit plain. Cold-based conditions imply that permafrost survived the last glacial cover. Based on the geomorphic evidence and estimates of Late Cenozoic erosion, we suggest that the present summit plains roughly represent the remains of a preglacial surface.

\begin{abstract}
J. Fjellanger \& L. Sørbel, Institute of Geosciences, Dept. of Physical Geography, University of Oslo, Box 1047 Blindern,NO-0316 Oslo, jakob.fjellanger@geo.uio.no.
\end{abstract}

The bedrock geomorphology in higher parts of inland Spitsbergen has until now received rather limited attention by geoscientists. The discussion has been focused on reconstructions of Pleistocene ice sheets and Cenozoic sedimentary budgets, mainly based on studies beneath the marine limit, or on recent glacial and periglacial processes. Studies of vitrinite reflectance (Manum $\&$ Throndsen 1978) and volume estimates of sediments offshore (Eiken \& Austegard 1987; Vorren et al. 1991) indicate that $2-3 \mathrm{~km}$ of rock has been removed from central Spitsbergen since the Eocene. It has been suggested that between $1 / 2$ and $2 / 3$ of this has been removed during the Pleistocene (Dimakis et al. 1998; Elverhøi, Dowdeswell et al. 1998). Thus it has been assumed that the bedrock geomorphology of central Spitsbergen is entirely the result of Quaternary sculpturing (Hjelle 1993; Dallmann 2002), and that the present debris cover and bedrock geomorphology of the summit plains are mainly of Holocene age (Y. Ohta, pers. comm. 2001). However, Harland (1997) has suggested a model for palaeosurface development with rather limited denudational lowering of the summit levels since the middle Neogene. Such a model resembles the situation on the Norwegian mainland where Tertiary landscapes, called the paleic surface, exist between deeply incised Quaternary valleys and fjords.

Topographic maps at a scale of 1:100000 published by Norwegian Polar Institute indicate little glacial sculpturing by Pleistocene ice sheets outside major valleys and fjords in central Spitsbergen. Lakes are scarce and mostly occur on lowlying sediment covered plains beneath the marine limit, and never on summit plains. This indicates that depressions and thresholds in bedrock are uncommon. Hanging valleys are almost nonex- 


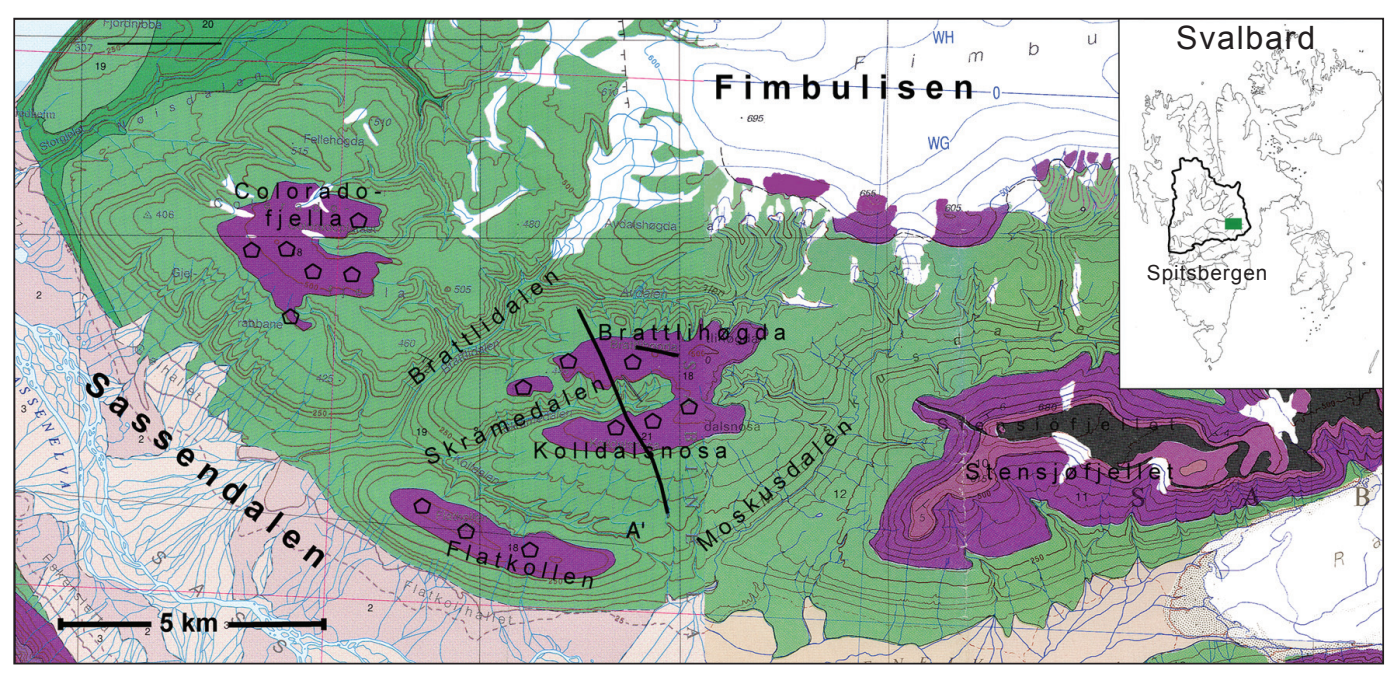

Fig. 1. Map of the study area, from geological maps of Adventdalen (Major et al. 2000), Agardhfjellet and Negribreen (Miloslavskij et al. 1992; Miloslavskij et al. 1996) (reproduced with permission of the Norwegian Polar Institute). The dolerite dyke is marked by a thick black line crossing Koldalsnosa and Brattlihøgda. The Kapp Starostin Formation is indicated in green and the Vikinghøgda Formation in purple. The dolerite sills are shown in brown and unconsolidated Quaternary deposits in Sassendalen in pink. The Isfjorden drainage area is shown on the inset map.

istent but V-shaped valleys are abundant. Many of the present glaciers seem to occupy V-shaped valleys, as, for example, has been revealed by radio-echo soundings on the Longyearbreen glacier (Etzelmüller et al. 2000). In addition, in situ weathered material is far more abundant than Pleistocene till, as shown, for example, on the Adventdalen map sheet (Sørbel et al. 2001). This may be quite different from many other parts of the uplifted continental margin, e.g. inland parts of the Norwegian mainland (Thoresen 1990), but is similar to the Varanger peninsula on mainland Norway.

Addressing these problems, and specifically focusing on the glacial impact during the Pleistocene, we have studied geomorphology and superficial materials at the Coloradofjella summit plain in central Spitsbergen. The term "summit plain" is here used to describe the horizontal, or sub-horizontal smooth surfaces that characterize mountain areas in central Spitsbergen.

\section{Study area}

Fieldwork was performed at Kolldalsnosa in the Coloradofjella area (400-500 m a.s.1.), east of the Sassendalen valley in central Spitsbergen (Fig. 1). An Early Cretaceous dolerite dyke reaches several metres above the summit plain (Major et al. 2000; Sørbel et al. 2001). The plain generally slopes towards the south (Fig. 2), roughly following the upper boundary of the chert-rich and resistant Kapp Starostin Formation, of Permian age (Major et al. 2000). Lower Triassic shale and siltstone belonging to the Vikinghøgda Formation forms the bedrock in parts of this plain. The boundary between these two formations is an erosional hiatus (Dallmann et al. 2001). Brattlidalen, Skråmedalen and Moskusdalen are up to $300 \mathrm{~m}$ deep V-shaped valleys sharply incised in the summit plain. Even though they are connected to shallow channels in the summit plain, most valley heads start abruptly, reaching considerable depth after a few hundred metres. Longitudinal profiles of the valleys are usually without steps, and stony colluvium from the Kapp Starostin Formation covers the valley sides. The summit plain is covered by regolith, which must be thick, as indicated by the extensive systems of ice wedge polygons (Fig. 3) (Sørbel \& Tolgensbakk 2002). Striae and glacially streamlined forms such as drumlins or fluted surface have not been identified anywhere in this summit plain. Lateral meltwater channels are also scarce (Tolgensbakk et al. 2000).

Uplift of the Svalbard region during the Cenozoic is at least in part related to the opening of the Greenland-Norwegian Sea (Dimakis et al. 1998). Along the western coast of Svalbard, the West 
Fig. 2. The regolith-covered, smooth and slightly sloping summit plain at Kolldalsnosa, Brattlihøgda and Coloradofjella mountains. The 200-300 m deep valleys Skråmedalen and Brattlidalen are incised and join the valley Sassendalen to the left. No glacial sculpturing has been identified on this surface. View to the west, August 2001.

Fig. 3. The fine-grained regolith has a smooth surface. A polygonal network of furrows underlain by ice wedges extends over large parts of the summit plain, indicating thick regolith. Note the protruding dolerite dyke in the background. Pit 1 is situated to the left in the photograph, by the dyke. The photograph was taken close to pit 3 , with a view to the west, August 2001.
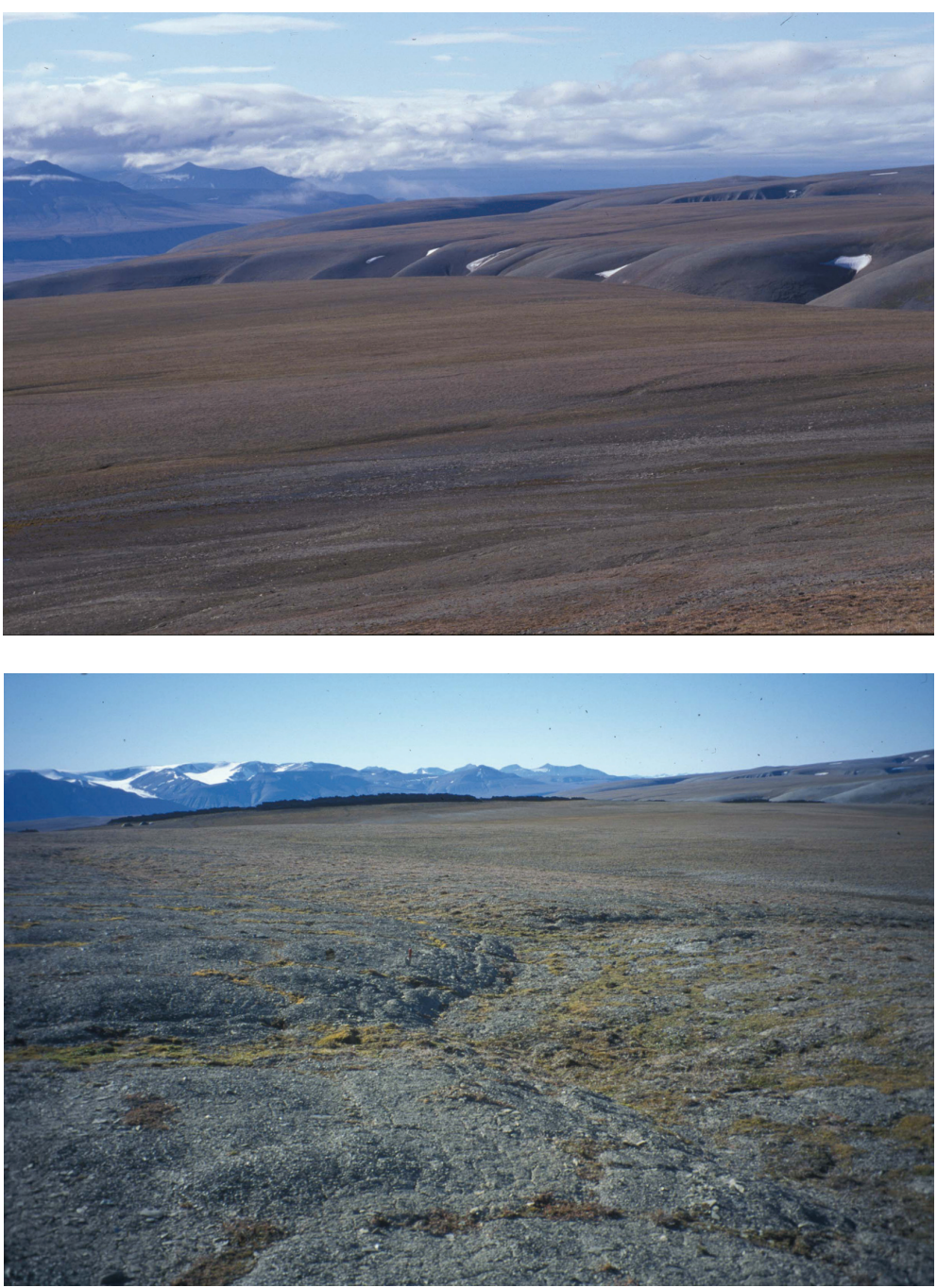

Spitsbergen orogeny is attributed to trans-pressional movements (Harland 1969). This changed the erosional supply of sediments into the Central Tertiary Basin from an easterly to a westerly source area (Steel et al. 1985). The study area is situated in the eastern part of the Central Tertiary Basin. Maturity studies of hydrocarbons (Mørk \& Bjorøy 1984) indicate maximum burial of ca. $2 \mathrm{~km}$ in the study area (A. Mørk, pers. comm. 2004). If the present altitude is added, a post-depositional uplift (relative to base level) on the order of $2.5 \mathrm{~km}$ is necessary to explain the subsequent erosion and development of the present land surface. The timing of this uplift is still uncertain (Harland 1997; Dimakis et al. 1998).

Precipitation in the study area has been mod- elled to be on the order of $300-500 \mathrm{~mm}$ per year (Humlum 2002). Mean annual air temperature (MAAT) at sea level in central Spitsbergen is currently around $-6^{\circ} \mathrm{C}$ (Førland et al. 1997). Based on a lapse rate of $0.5^{\circ} \mathrm{C}$ per $100 \mathrm{~m}$, the MAAT in the study area is assumed to be close to $-8^{\circ} \mathrm{C}$. The equilibrium line altitude for glaciers in the area is presently about $500 \mathrm{~m}$ a.s.l. (Hagen et al. 1993). The nearest glacier is Fimbulisen, an ice cap $5 \mathrm{~km}$ to the north-east (Fig. 1). In addition, there are perennial snowfields, mainly at the heads of nearby V-shaped valleys (Fig. 2). 


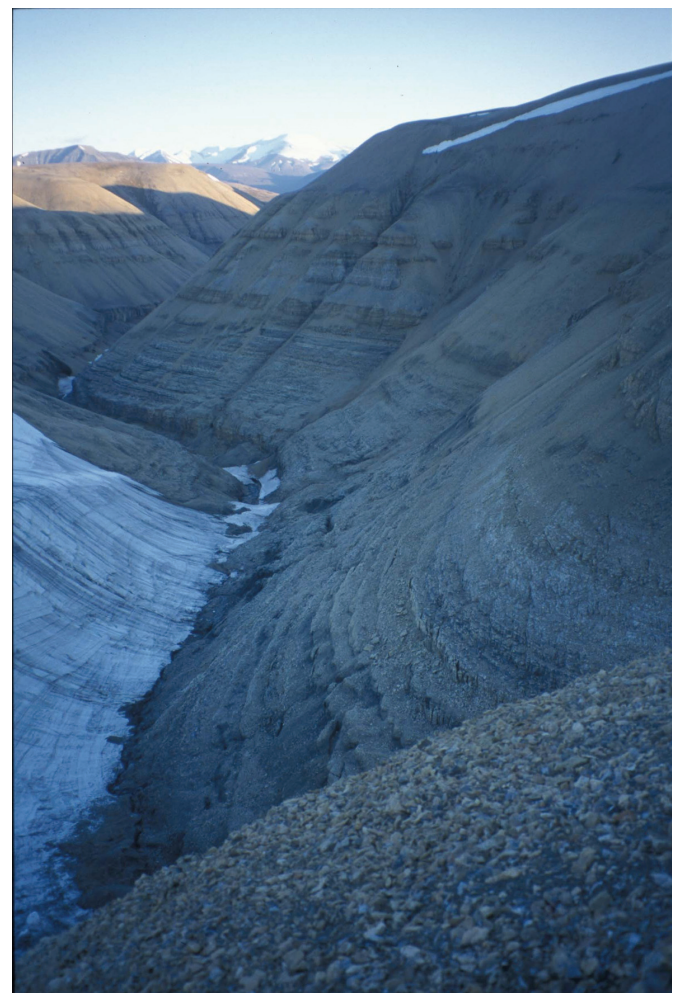

Fig. 4. Upper part of Brattlidalen. The V-shaped cross-section of the valley is clearly cut in the bedrock, which consists of chert-rich rocks of the Kapp Starostin Formation. The end of an outrunner from the Fimbulisen ice cap is seen in the lower left. During the Little Ice Age (ending around 1900) this coldbased glacier tongue covered more of the valley, preventing the valley side from being buried by talus material. View to the south-west, August 2001.

\section{Methods}

The field survey was mainly carried out from 3 to 11 August 2001, but parts of the area have also been surveyed in connection with earlier geomorphological mapping (Sørbel et al. 2001). Three main pits and several smaller ones were excavated to examine the soil stratigraphy and to collect samples for analyses of grain size distribution and mineralogical composition. Two pits were dug into the permafrost, exposing ice wedges. A Wacker gasoline driven sledge hammer was used to dig through one of these ice wedges (pit 1). A hand-driven ice auger was used to measure vertical thickness of the other exposed ice wedge (pit 3 ). Rock-clasts lying on the ground and presumed to derive from the local bedrock were sampled for comparisons of mineral composition. Mapping of regolith thickness was attempted using a pulsEKKO ground penetrating radar with $50 \mathrm{MHz}$ and $100 \mathrm{MHz}$ antennas during snow-free conditions in August 2001, and using a Ramac ground penetrating radar with $50 \mathrm{MHz}$ antennas on a sledge pulled by a snowmobile in the period 1521 April 2002.

Grain size distribution was calculated from weight fractions separated by wet sieving though a $63 \mu \mathrm{m}$ sieve, and measurement of clay fraction by X-ray diffraction in a Sedigraph micromeritics 5000D. The samples had previously been dispersed in calgon-water $(1 \mathrm{~g}$ calgon per litre distilled water) for 48 hours. The samples were put in an ultrasound bath for 5 minutes before and after the dispersion period. Mineral content both on unoriented (bulk) and oriented (smear slides of clay fraction) samples were analysed in a Philips X'Pert MPD, X-ray diffractometer (XRD), with a $\theta-\theta$ goniometer. For clay fraction (smear slides), the recording was done on untreated slides as well as after ethylenglycol treatment and heating $\left(550^{\circ} \mathrm{C}\right)$. However, problems with flocculation increased the errors associated with the quantification of the clay fraction and also blurred the clay mineral analysis resulting from poorer smear slide preparations.

\section{Results}

\section{Surface observations}

The summit plain is very flat over large areas, especially where bedrock consists of the Kapp Starostin Formation (Fig. 2). The smooth surface of the regolith that covers the summit plain (Figs. 2, 3) exhibits no signs of glacial shaping, such as flutes or drumlins. The valleys dissecting the plain can exceed $10 \mathrm{~km}$ in length, are up to $1 \mathrm{~km}$ wide at the top and $300 \mathrm{~m}$ deep. Their perfect V-shape is developed in the bedrock, mainly the chert-rich Kapp Starostin Formation, and is thus not a result of talus infilling (Fig. 4).

The protruding dolerite dyke is nearly $4.5 \mathrm{~km}$ long, 2-2.5 m wide and penetrates the host rock vertically, although in some places leaning somewhat towards the west. At Kolldalsnosa it penetrates the shale of the Vikinghøgda Formation and protrudes up to more than $4 \mathrm{~m}$ above the adjacent surface (Figs. 3, 5). At Brattlihøgda, north of the Skråmedalen, the dyke reaches about $1 \mathrm{~m}$ above 
Fig. 5. West-facing side of the protruding dolerite dyke. An abundance of blocks from the dyke are seen beside it. The wall is part of a vertical dykeparallel crack. The original dyke wall was about $0.5 \mathrm{~m}$ further out and is preserved some metres behind the researcher. View to the south-south-east.

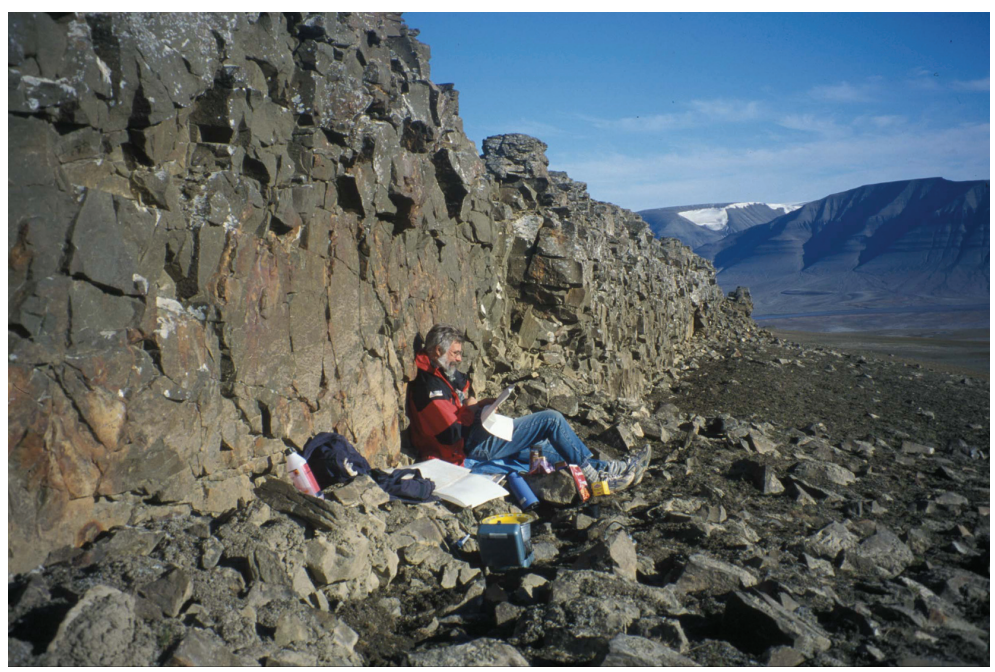

the ground. Striations have not been observed on the dyke. The ground surface on both sides of the protruding dyke slopes away, making the dyke protrude at a small crest in the terrain (Fig. 3).

Vertical cracks along the dyke facilitate the disintegration of the dyke, leaving straight vertical walls on the remaining parts (Fig. 5). The cross- section illustrated in Fig. 6 is a little further south and shows that the ground surface on the western side is up to $2 \mathrm{~m}$ lower than east of the dyke.

Diamicton sheets with angular dolerite clasts of gravely to bouldery size, clearly originating from the dyke, cover the ground on both sides of the dyke. At the crest of Kolldalsnosa, where the dyke

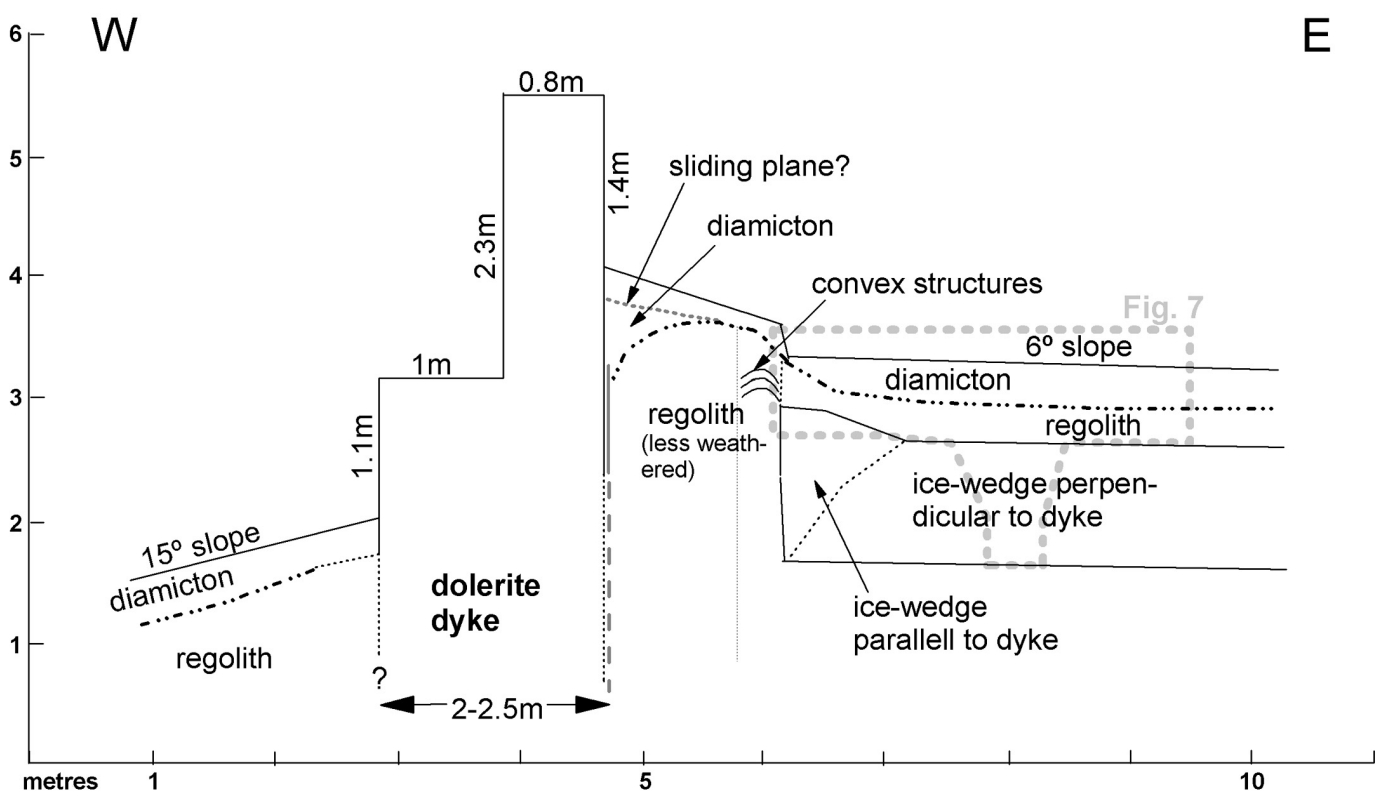

Fig. 6. Cross profile of dyke by pit 1 . Note the junction of ice wedges. The thick grey line along the eastern dyke wall below the ground represents gypsum crystals that cover the dyke wall at the contact with the hosting shale, and thin layer of light brown fine-grained sediment. Convex structures in the shaly regolith to the left of the dyke-parallel ice wedge have probably resulted from laterally directed forces during ice wedge growth. 


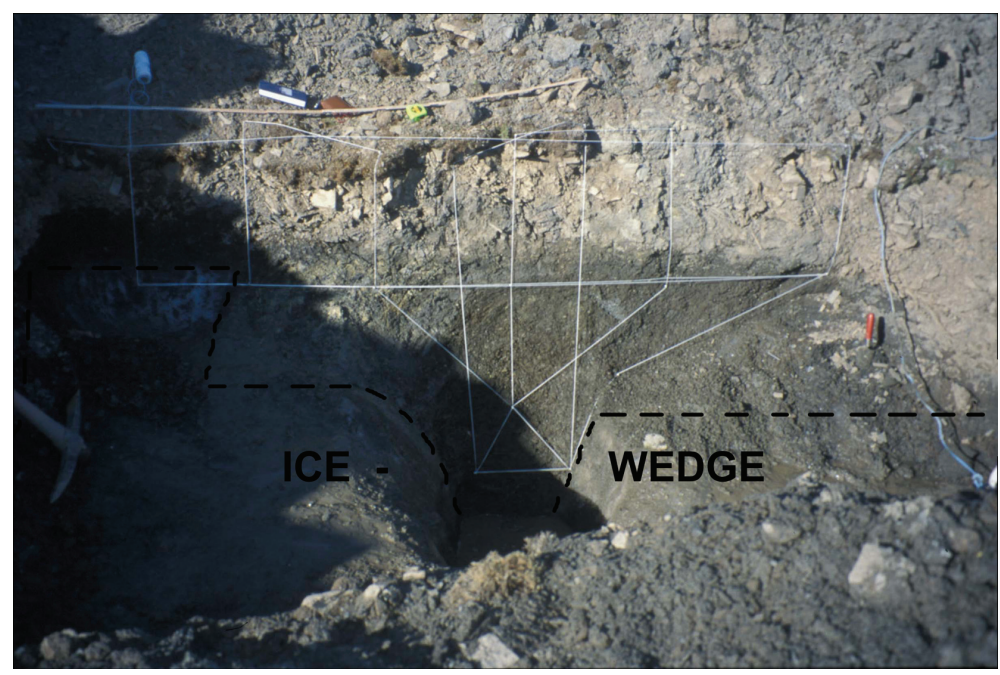

Fig. 7. Pit 1 was dug along an ice wedge, coming in from the right and meeting the dyke-parallel ice wedge to the left in the picture. The pit is about $1.7 \mathrm{~m}$ deep (including the water at the bottom). The rope net starts at the ground surface and reaches $1.2 \mathrm{~m}$ depth. The $30 \mathrm{~cm}$ thick diamicton layer clearly seen in the upper part of the soil is underlain by in situ weathered shale. See Fig. 6 for position relative to dyke.

stands tallest, the diamicton sheets have their smallest extent, reaching about $1 \mathrm{~m}$ towards the east and 5-10 m towards the west. In the area of pit 1 the diamicton sheet reaches about $20 \mathrm{~m}$ east of the dyke, and is bordered by a weakly developed drainage channel in a slight depression sloping towards the south. West of the dyke, where the adjacent ground has its largest slope angle $\left(15^{\circ}\right)$, the diamicton reaches its maximum extent (about $100 \mathrm{~m}$ ) and several lobe fronts occur at different distances.

An abundance of gravely to bouldery angular erratics of gabbroid rocks, clearly more coarsegrained than the dolerite dyke, has been distributed over the entire Kolldalsnosa summit plain. Within a randomly selected $10 \times 10 \mathrm{~m}$ square situated at UTM E556055 N8693163 (ca. $440 \mathrm{~m}$ a.s.1.), about $250 \mathrm{~m}$ east of the dyke, 78 gabbro erratics $(>5 \mathrm{~cm}$ in diameter) were counted. The erratics are only found superimposed on the regolith. Some are clearly more weathered on the upfacing side as indicated by rough surface texture. Gabbroid erratics, although much less abundant, were also found at Flatkollen, closer to Sassendalen, and at Coloradofjella to the north-west (Fig. 1). However, there are no reports of such erratics from west of Sassendalen.

The surface of the regolith in large parts of the summit plain features networks of non-sorted polygons $10-70 \mathrm{~m}$ in diameter, with each polygon furrow being 2-5 m wide. Several pits (see below) confirm that the furrows are underlain by ice wedges (Figs. 3, 7) as also was reported by Sørbel \& Tolgensbakk (2002) at about same alti- tude west of Sassendalen. One ice wedge parallels the dyke at a distance of 1.5-2 m, and is connected to other ice wedges by right angled ice wedge joints.

A few shallow deflation scars on the top of a rounded summit about $0.4 \mathrm{~km}$ east of the dyke, indicate slight aeolian erosion on this exposed site. Some platy clasts, up to $10 \mathrm{~cm}$ in diameter, that have been left on the ground surface are assumed to represent more resistant layers of the parent rock.

\section{Excavations and sedimentological investigations}

All the pits were dug within a $500 \mathrm{~m}$ range east of the dyke, and where bedrock consists of the shale of the Vikinghøgda Formation (Fig. 1). Pit 1 (UTM E555678 N8693018) was dug through an ice wedge, close to an ice wedge joint $3 \mathrm{~m}$ east of the dyke, reaching a depth of $1.7 \mathrm{~m}$ (Figs. 3, 7). The partly fine-grained superficial material is clearly derived from the bedrock, preserving its shaly structure. It must be considered a regolith and its thickness is at least $2 \mathrm{~m}$. The thawed layer was 50-60 cm thick. At $70 \mathrm{~cm}$ depth the ice wedge was reached, exposing a smooth top surface. The ice wedge was $1 \mathrm{~m}$ wide at the top and about $1 \mathrm{~m}$ deep, and did not reach the bottom of the regolith. The ice contains air bubbles and has incorporated small amounts of dark (probably mineralogical) fine-grained material.

The stratigraphy in pit 1 shows a $30 \mathrm{~cm}$ thick diamicton on top, containing angular doler- 
ite clasts in a fine-grained matrix. The diamicton was underlain by a silty material. At $50 \mathrm{~cm}$ depth $80-85 \%$ was silt, $15-20 \%$ was clay and less than $1 \%$ was larger than silt. The material becomes coarser towards the bottom of the pit, with $70-75 \%$ being larger than silt (up to $3 \mathrm{~cm}$ in diameter at $1.55 \mathrm{~m}$ depth), but still clearly being a regolith. Ground penetrating radars were used in an attempt to map variations in thickness of the superficial material cover. However, the radar profiles do not show any clear horizons below ground surface.

Pit 2 (UTM 556048 8693154) was dug about $0.4 \mathrm{~km}$ east of the dyke, close to the rounded summit mentioned above. The permafrost table was reached at $50 \mathrm{~cm}$ depth, where a regolith sample was collected. The shaly structure from the parent rock is well preserved in the pit walls (Fig. 8). More than $98 \%$ is silt or clay, the rest being sand-sized, which roughly equals the sample from the same depth in pit 1. Pit 3, about $40 \mathrm{~m}$ west of pit 2 , showed that a $4 \mathrm{~m}$ wide furrow was underlain by a $2 \mathrm{~m}$ wide ice wedge. The active layer was about $50 \mathrm{~cm}$ thick and the ice wedge was reached at about $65 \mathrm{~cm}$ depth. Several borings indicated a maximum ice wedge depth of $60 \mathrm{~cm}$. A sample from beneath the ice wedge shows that the regolith continues downwards, and is therefore at least $1.3 \mathrm{~m}$ deep.

Microscope study of the samples from pits 1 and 2 revealed an abundance of white grains identified as gypsum. Gypsum was also found as 2-4 $\mathrm{mm}$ crystals in a brownish coloured $1-2 \mathrm{~cm}$ thick marginal zone along the dyke. XRD analysis of the regolith from pit 2 and of rock clast found on the ground surface nearby was done on bulk samples (Fig. 9) and the clay fraction. XRD analysis of the regolith from pit 1 was only done on bulk samples due to flocculation problems. Despite the formation of gypsum, leakage of small amounts of carbonates (dolomites) and possibly slight clay mineral transformations, mineralogical analysis of the regolith does not indicate significant chemical differences compared to the rock clast. XRD analysis of bedrock samples from the same stratigraphic unit collected in Deltadalen, west of Sassendalen (supplied by A. Mørk) support that the rock clast may be regarded as representing the bedrock.

Very few indications of cryoturbation have been observed at Kolldalsnosa. Small water content and small variation in clast size in the upper part of the regolith may limit cryoturbation.

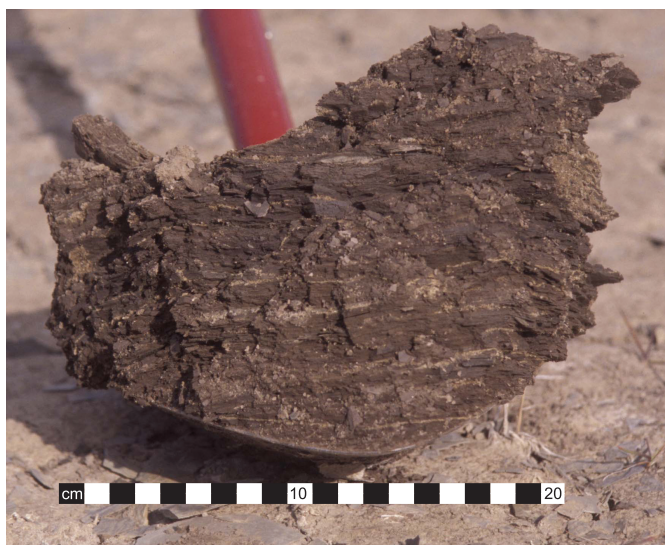

Fig. 8. Silty regolith sampled in the active layer $0.4 \mathrm{~km}$ east of the dyke. Shaly structure from the parent rock is well preserved.

\section{Discussion}

\section{Erratics and glaciation}

The abundance of gabbroid erratics at the summit plain of Kolldalsnosa clearly shows that the area has been glaciated at least once. The erratics are probably derived from summits in the east, capped by dolerite sills (Y. Ohta, pers. comm. 2001). The most likely source area is the mountain of Stensjøfjellet, east of the $300 \mathrm{~m}$ deep valley Moskusdalen (Fig. 1). This indicates deposition by a rather thick glacier moving independently of local topography. It is, however, unlikely that subglacial plucking caused the incorporation of material in the ice. Subglacial plucking would not account for the preservation of the dyke at Kolldalsnosa, which must have survived at least the last glaciation (see below). A possible explanation is that deposition occurred during a late stage of the glaciation shortly after the summit of Stensjöfjellet became ice free. Dolerite clasts from the summit area (680 - $750 \mathrm{~m}$ a.s.1.) could then fall down onto the surface of a glacier, mainly following Sassendalen, but also overrunning the Kolldalsnosa area (450 m a.s.1.).

According to glacial reconstructions (Mangerud et al. 1992; Salvigsen et al. 1995; Landvik et al. 1998) the area was covered by an ice sheet crossing Spitsbergen from east to west during the Late Weichselian maximum. The deposition of the erratics may originate from this late event or from earlier glaciations. 


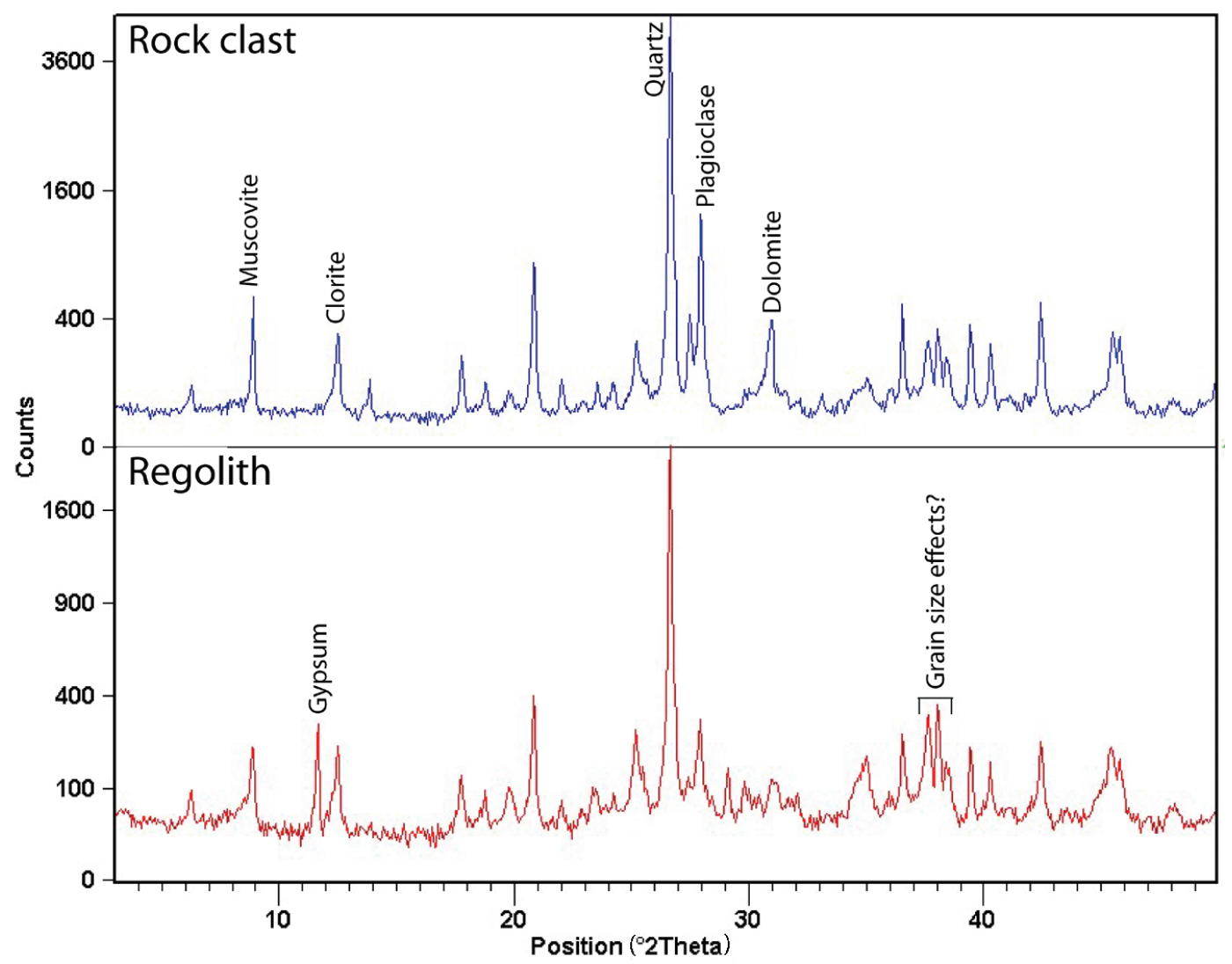

Fig. 9. XRD analysis of bulk samples for rock clast assumed to represent bedrock and for regolith in pit 2 sampled at $50 \mathrm{~cm}$ depth (bottom of the active layer).

\section{Age and formation of regolith}

Working partly in the same geological formations on Barentsøya, east of Spitsbergen, Büdel (1982) found that the bedrock was heavily disintegrated by the growth of ice lenses in the upper part of the permafrost, a process he called "the ice rind effect". In these layers, ice constituted up to $60 \%$ of the total volume. However, in the pits (1 and 3) at Koldalsnosa we did not observe any ice lenses in the permafrost outside the ice wedges. Further, it is unlikely that total disintegration of a rock to a silty material, leaving the shaly structure of the parent rock unaltered, could have resulted from a frost-related mechanical processes such as frost wedging or ice lens growth. Therefore, we assume that the "ice rind effect" has not been important for the disintegration process.

Comparison with bedrock indicates only a slight mineralogical change, mainly some forma- tion of gypsum, some leaching of carbonates and possibly some formation of mixed layer minerals. We suggest that processes connected to wetting and drying (White 1976), possibly enhanced by cycling through the freezing point (Hudec 1973; Ballantyne \& Harris 1994), in combination with the slight chemical change, have disintegrated the rather weak parent shale. Thus, the disintegration process seems restricted to the active layer during the few annual months of thaw in glacierfree periods.

From the summit plain at Barentsøya, Büdel (1982) reported active layer thicknesses of $30-40 \mathrm{~cm}$ for the 1959, 1960 and 1967 fieldwork seasons. He also reported relict active layers, radiocarbon dated to about $3000 \mathrm{BP}$, reaching depths of $60-80 \mathrm{~cm}$. According to Førland et al. (1997), in the 1950-1970 period, the meteorological stations in Svalbard had the coldest summer temperatures (June-August) since the Little Ice Age, 
also being about $0.5^{\circ} \mathrm{C}$ colder than at the end of the 20th century. Based on this and the active layer thickness on Kolldalsnosa being $50-60 \mathrm{~cm}$ thick in a warm and dry season like that in 2001, we assume that the active layer in the Coloradofjella area during the Holocene climatic optimum would have been of about the same thickness as reported from Barentsøya.

Assuming that regolith formation is not connected to processes in the permafrost and maximum Holocene active layer thickness is of the same order of magnitude as that on Barentsøya, a regolith cover of at least $2 \mathrm{~m}$ thickness must be older than the Holocene. Further, regolith development underneath a glacier is unlikely, specifically if the glacier is cold-based (see below). Thus, the regolith seems to predate the Late Weichselian glaciation.

\section{Diamicton sheets and dyke emergence}

The diamicton sheets found on both sides of the dyke are interpreted to have been emplaced mainly by solifluction processes. This was the only sign of creep movement observed in the summit plain. Angular clasts consisting of fine-grained dolerite have been supplied by weathering of the dyke. The fine-grained matrix is derived from the underlying sedimentary bedrock, indicating that weathered regolith existed before the diamicton was emplaced. The extent of the diamicton sheets seems dependent on the angle and length of the sloping ground and the amount of dolerite clasts delivered from the dyke. Dominating winds from the south-east, creating larger snow banks on the western side of the dyke, may also have played a role in the extension of the sheets through a larger supply of water to the solifluction movement.

Another mechanism of possible clast delivery at some distance from the dyke is sliding on the icy surface of snow in early summer. Erosion on the surfaces adjacent to the dyke may have occured by slope wash, as indicated by observed concentrations of gravels and stones in tracks of meltwater leading from snow banks by the dyke. This process will mainly remove fine-grained material from the surface of the diamicton.

Solifluction is completely absent from many slopes in central Spitsbergen despite large amounts of fine-grained material (Tolgensbakk et al. 2000; Sørbel et al. 2001). A combination of factors - the shallowness of the active layer, limiting the amount of frost heave; snow-melt occur- ring largely when the ground still is frozen; and low precipitation - probably result in rather small rates of movement of the sheets by the dyke.

The cross-section of the dyke by pit 1 (Fig. 6) shows that the highest free face of the dyke at that location is towards the west, corresponding to where the adjacent ground has the largest slope angle and where the diamicton sheet has its largest extent. This indicates that solifluction transport of weathered material has played a role in the emergence of the protruding dyke. However, such a mechanism for dyke emergence requires that the lowering rate of the adjacent surface is greater than the lowering rate of the dyke itself delivering clasts to the diamicton. The fact that the dyke protrudes highest where the sheets on both sides have the smallest extent clearly indicates that solifluction cannot fully explain its emergence.

These observations show that even if some periglacial sediment transport away from the dyke may have happened during the Holocene, it was never enough for more than $4 \mathrm{~m}$ of dyke to emerge. Estimates of Holocene sediment yield from unglaciated areas calculated at between 30 and 70 metric tons per $\mathrm{km}^{2}$ and year (Elverhøi, Hooke et al. 1998) supports this conclusion. With sediment densities of $1800 \mathrm{~kg} \mathrm{per} \mathrm{m}^{-3}$, this results in a total land surface lowering of between 15 and $40 \mathrm{~cm}$ (not corrected for rock densities) for the entire Holocene.

Thus, it is most likely that the dyke, actually resembling a tor, has survived the Late Weichselian glaciation. This result may be tested by means of cosmogenic radionuclide exposure age of the dyke. A model with glacially eroded rock surface, where the top of the dyke was levelled with the adjacent ground at the end of the Late Weichselian glaciation, seems unrealistic. This would require weathering and evacuation of more than $4 \mathrm{~m}$ of rock during the Holocene. We have not found any traces of such a strong erosional event, such as extensive, well developed drainage systems in the summit plains or remaining deposits of fine grained sediments in the V-shaped valleys. In addition, the numerous erratics of different sizes still linger on the surface, indicating very limited erosion since deglaciation.

\section{Age of ice wedges}

Assuming that the climate at the onset of the Late Weichselian glaciation was at least as cold as during the late Holocene, ice wedges proba- 
bly existed in the summit plains on Spitsbergen at that time. Sørbel \& Tolgensbakk (2002) have indicated that such ice wedges might have survived the Late Weichselian ice sheet due to coldbased conditions. It may then be asked if such ice wedges could have survived the Holocene.

In Finnmark, northern Norway, ice wedge casts developed on ice-marginal deposits close to sea level are assumed to be of Younger Dryas age or older (Svensson 1962; Sollid et al. 1973). Deglaciation of valleys and coastal areas in central Spitsbergen seems to have happened later, radiocarbon dated to between 10000 and $9500 \mathrm{yr}$ BP (Salvigsen \& Mangerud 1991; Mangerud et al. 1992). During the same period, influx of warm Atlantic water (Vorren et al. 1988) led to rapid temperature increase in the western and south-eastern Barents Sea (Hald \& Dokken 1995). This also affected the west coast of Spitsbergen, where growth of the bivalve Mytilus edulis, later extinct around Svalbard, indicates the arrival of warmer water prior to $9500{ }^{14} \mathrm{C}-y r$ BP (Salvigsen et al. 1992). Along the east coast, equally warm water arrived prior to $8800{ }^{14} \mathrm{C}$-yr BP (Hjort et al. 1995). Thus, summer surface temperatures are assumed to have been about $1{ }^{\circ} \mathrm{C}$ warmer than at present, periodically reaching at least $3{ }^{\circ} \mathrm{C}$ above recent values, especially in sheltered locations like the inner parts of some fjords (Salvigsen et al. 1992). For the period $8000-4000{ }^{14} \mathrm{C}-\mathrm{yr}$ BP, Birks (1991) assumed a mean July air temperature up to $2^{\circ} \mathrm{C}$ higher than at present, based on analysis of organic sediments and pollen preserved in a lake at the western coast of Spitsbergen.

A late 20th century warming evident in air temperature series (Førland et al. 1997) seems to be paralleled by higher sea surface temperatures, reflected by findings of living $M$. edulis at Bjørnøya (Weslawski et al. 1997) and perhaps even in Isfjorden (Sandberg 2004).

Generally, it is assumed that ice wedges may develop at MAAT up to -5 or $-6^{\circ} \mathrm{C}$ (Washburn 1979). This is $2-3^{\circ} \mathrm{C}$ warmer than the present MAAT in the study area. Ice wedges are presently active in areas close to sea level, for instance in the valleys of Adventdalen and Reindalen, where MAAT is close to $-5^{\circ} \mathrm{C}$ and in some years significantly higher (Jeppesen 2001). It therefore seems reasonable to assume that ice wedges developed and/or were preserved in the Kolldalsnosa summit plain during the early Holocene. Assuming that they had the same depth as at present, for example, due to equally thick regolith, melt- ing of the ice wedges later in the Holocene would require an active layer of more than $1.5 \mathrm{~m}$. This seems unlikely (see above).

The ice wedges within the study area are generally very wide compared to their depth. The ones exposed in pits 1 and 3 are 1 and $2 \mathrm{~m}$ wide and 1 and $0.6 \mathrm{~m}$ deep, respectively. This suggests a long period of formation as the contracting soil layer is rather thin, as shown by the depth of the ice wedges. The width of the furrows seems to be much wider than the ice wedges themselves. Above the $2 \mathrm{~m}$ wide ice wedge in pit 3 a $4 \mathrm{~m}$ wide furrow had developed. Thus, during periods of formation the ice wedges may have had a wider upper part, which subsequently melted due to increase in active layer thickness. This indicates that the period of formation was followed by a period with a thicker active layer.

Horizontal top surfaces of the ice wedges and deformational structures in the hosting regolith (Fig. 6) indicate epigenic ice wedge development. Upward extension of the ice wedges, e.g. in a stepwise manner as shown by Ballantyne \& Harris (Fig. 4.4 in Ballantyne \& Harris 1994), has not been observed. Assuming that pre-existing ice wedges did not melt during the Holocene climatic optimum, the lack of upward extension supports that they have not been active in later periods. The ice wedge furrows were not, or were only weakly, developed in the surface of the diamicton along the dyke, while they were clearly more developed outside the diamicton. This suggests that ice wedge formation more or less had ceased when the diamicton was emplaced.

Based on the analysis of the Holocene climate, inferred active layer thickness and indications that ice wedge development ceased some time ago, it is not unlikely that the ice wedges within the study area have survived the Holocene, and might even predate the Late Weichselian.

\section{Implications for permafrost and ice sheet temperatures}

Our study largely confirms the results presented by Sørbel et al. (2001) and Tolgensbakk et al. (2000). In top areas, tor-like features, including protruding dykes like the one at Kolldalsnosa, are common. Covers of in situ weathered superficial material dominate down to about 300-400 $\mathrm{m}$ a.s.l. Till from Pleistocene ice sheets (covering about $5 \%$ of the glacier-free areas on the Adventdalen map sheet) and striations have been 
found only at lower altitudes. The highest reported striae are at $195 \mathrm{~m}$ a.s.l., at the brink above the southern wall of Tempelfjorden (Humlum et al. 2003) about $12 \mathrm{~km}$ north-west of the study site. Lateral meltwater channels do occur, but are not common and give little basis for reconstruction of the deglaciation (Sørbel et al. 2001).

The protruding dyke, the thick regolith and the lack of traces of glacial erosion, in combination with the abundance of erratics suggest that the Late Weichselian ice sheet was cold-based during the whole period of its existence on the Kolldalsnosa summit plain. The thickness of the permafrost, and even features like ice wedge polygons in the summit plains, should therefore be evaluated in a longer time perspective than the post-glacial period. A further implication is that the area with cold-based conditions during the last glaciation is larger than earlier assumed (Landvik et al. 1988).

While cold-based conditions lingered during the deglaciation (Sollid \& Sørbel 1988a, 1988b), it might be asked why so few lateral meltwater channels seem to have been created. The last ice masses on the summit plains may have had the form of gentle ice caps, perhaps similar to the one currently covering the plateau of Bassen, at Operafjellet, in central Spitsbergen (Sørbel et al. 2001). In such a situation the meltwater largely is drained in a supraglacial position, leading to protection of the ground surface. When the ice cap on the summit plain had become very thin and started disappearing along its margins, the meltwater must have drained on the ground surface. However, the concentration of flow, and therefore the potential for erosion, was limited due to low production of meltwater, rapid change of ice margins and the exposed ground being nearly horizontal.

In the broader valleys draining large amounts of ice, warm-based conditions have existed in periods during the Late Weichselian (Humlum et al. 2003). Thus, in areas below about $300 \mathrm{~m}$ a.s.l. the permafrost and associated features, like ice wedge polygons and pingos, are most probably post-glacial (Jeppesen 2001; Sørbel \& Tolgensbakk 2002). Temperature data from the borehole at the hill of Jansonhaugen, in Adventdalen, indicate that the permafrost had been created in post-glacial times (Isaksen et al. 2000). In higher lying areas the permafrost is up to $500 \mathrm{~m}$ thick (Liestøl 1977), indicating a considerably greater age (Humlum et al. 2003).

\section{Pleistocene glacial erosion}

Our study suggests that the geomorphological features and regolith on summit plains in central Spitsbergen have survived at least the last Weichselian glaciation. That geomorphic features on Spitsbergen have been perfectly preserved underneath the Late Weichselian ice sheet, due to coldbased conditions, has been concluded by several authors, including Lehman \& Forman (1992) and Mangerud et al. (1992). In addition, up to 1 My old sediments have been found along Kongsfjorden (Miller 1982; Houmark-Nielsen \& Funder 1999), and sediments surviving the Weichselian glaciations have been found, for example, in inner and outer parts of Isfjorden, in Recherchefjorden and at Amsterdamøya in the north-western corner of Spitsbergen (Miller et al. 1989; Landvik et al. 1992; Mangerud et al. 1992; Landvik et al. 2003). This clearly indicates that glacial erosion, even in certain areas along the fjords, has been limited since the Middle or Late Pleistocene (Mangerud et al. 1996). Thus, the bedrock geomorphology in many areas at least predates the Late Pleistocene.

Beneath ice sheets erosion will usually be concentrated along pre-existing valleys, where ice is thicker and warm-based conditions are more easily reached. In central Spitsbergen, elevated summit plains are bordered by incised valleys and fjords. The summit plains are often controlled by resistant geological formations. Elverhøi et al. (1995) have suggested that highly erosive local glaciers in interstadials and interglacials are the main agents of denudation onshore Spitsbergen during the Pleistocene. However, the lack of cirques and other traces of erosion by local glaciers within these summit plains indicate that other processes must be invoked to explain their denudation and present geomorphology.

The size of the V-shaped valleys, which must have been developed during periods without glacial cover, indicates that they must be older than the Holocene. The V-shaped cross-sectional form must have been preserved underneath the covering ice sheets, supporting cold-based conditions. Meltwater from perennial snow banks currently drains through the valleys. However, firn underlain by permafrost will protect the valley bottoms during summer, as observed in some of the valleys. In addition, rates of precipitation in these areas are small (Humlum 2002). The present rate of valley development therefore seems to be small, pushing their origin back in time. 
Thus, it seems clear that non-glacial denudation processes are responsible for the formation of the summit plains as for the V-shaped valleys. Our study indicates that very little denudation occured during the Holocene in the Kolldalsnosa summit plain. Consequently, if the Holocene is typical of the glacier-free periods during the Pleistocene then very little denudational lowering can be attributed to these periods.

Estimates of erosion, compiled from several studies of maximum burial of rocks at Svalbard and underneath the Barents Sea, led Dimakis et al. (1998) to suggest an average denudation of 1-2 $\mathrm{km}$ for the Spitsbergen area during the Late Pliocene and Pleistocene. Equally high erosion has been estimated from volume calculations of offshore fan deposits (Hjelstuen et al. 1996). This implies that scarcely any of the present landscape on Spitsbergen is of preglacial age. However, there are considerable uncertainties - on the order of \pm 200 - $500 \mathrm{~m}$ or even $\pm 1000 \mathrm{~m}$ according to Dimakis et al. (1998) - with the maximum burial estimates. Concerning the offshore sediment volumes, only one drilling (ODP leg 986) has penetrated the anticipated glacigenic part of the fans offshore Spitsbergen, and dating partly relies on seismic correlation with bore holes in the Bjørnøya fan about $450 \mathrm{~km}$ further south (Forsberg et al. 1999). Further, provenance studies indicate that considerable volumes in the lower fan parts derive from the Storfjorden or Barents Sea area (Forsberg et al. 1999; Smelror 1999; Butt et al. 2000), having been transported northwards to their present position by sea currents. This volume should therefore largely be excluded from the Isfjorden drainage area sediment budget.

So far the volume of sediments in the submarine fans offshore the Isfjorden area has only been determined for the section younger than $200 \mathrm{Ky}$, amounting to $328 \mathrm{~km}^{3}$ (Elverhøi, Hooke et al. 1998). From data presented by Hjelstuen et al. (1996), the sediments younger than $200 \mathrm{Ky}$ represent $6.9 \%$ of the total glacigenic deposition in the Storfjorden fan, south-west of Spitsbergen. By using the same proportion, the total glacigenic sediment volume in the Isfjorden fan is calculated to $4750 \mathrm{~km}^{3}$. Evenly distributed over the present Isfjorden drainage area (Fig. 1), which is $9540 \mathrm{~km}^{2}$ (including the fjord), this would yield a $500 \mathrm{~m}$ thick sediment layer. Converting this to bedrock erosion will probably result in some thickness reduction due to density differences (Vorren et al. 1991). The masses that were removed during the last 2.3 to 2.5 My may be even smaller, as the first ice streams draining out Isfjorden may have eroded preglacial deltaic depositions at the coast. Thus, this unknown amount was already removed from the drainage area at the onset of the large glaciations, but was not necessarily incorporated in the preglacial part of the present fan. An additional reduction results if the source area was larger than the present Isfjorden drainage area, incorporating areas further east (Elverhøi et al. 1995), as ice drained across Spitsbergen during peak glaciations (Mangerud et al. 1992; Salvigsen et al. 1995; Landvik et al. 1998). A further reduction may be linked to Pleistocene formation of the strandflat and its continuation offshore, yielding sediments to the offshore deposits.

Within the Isfjorden drainage area maximum fjord depth is approximately $400 \mathrm{~m}$ b.s.l. The highest peaks reach approximately $1300 \mathrm{~m}$ a.s.1. and average elevation is $260 \mathrm{~m}$ a.s.l. (including the fjord basin). Adding less than $500 \mathrm{~m}$ as average can reasonably be done without adding anything to the summit plains, as the internal relief of the preglacial landscape probably was much less than at present. As a rough validating test a trend surface was constructed starting at the present summit plains, using GIS techniques and a digital elevation model with $500 \mathrm{~m}$ resolution. Subtracting today's landscape from the trend surface indicates that the missing volume $\left(5400 \mathrm{~km}^{3}\right)$ is of the same order of magnitude as the glacigenic sediments in the submarine fan (see above). Based on this, and the geomorphic evidence presented in this work, we suggest that the present summit plains, including the rather low-lying one in the Coloradofjella area, represent the remains of a preglacial surface. This is in agreement with the palaeosurface model proposed by Harland (1997).

\section{Conclusions}

The Coloradofjella area, featuring a smooth regolith covered summit plain with deeply incised Vshaped valleys, has been overrun by at least one thick ice sheet moving from east to west, depositing an abundance of coarse-grained dolerite erratics. The distribution and lithology of the erratics indicate dolerite capped mountains $5-10 \mathrm{~km}$ to the east as the most likely source. A protruding fine-grained dolerite dyke has emerged through 
weathering and subaerial denudation of the adjacent ground. Sediment evacuation by solifluction of the present diamicton sheets alone cannot explain its emergence. A model with glacial abrasion during the Late Weichselian, levelling the top of the dyke with the adjacent bedrock, and Holocene weathering and erosion leaving the dyke protruding up to $4 \mathrm{~m}$ above the adjacent ground, seems unrealistic. The geomorphology and regolith cover indicates that the overrunning Late Weichselian ice sheet have not eroded these summit plains. The bedrock geomorphology and the regolith cover must therefore be older.

To summarize, we suggest that the Late Weichselian ice sheet was cold-based throughout its existence in the summit plain of Kolldalsnosa. This implies that the permafrost and possibly even the ice wedges may be older than the last glacial cover. Based on the geomorphic evidence and the erosion estimate, we suggest that the present summit plains in central Spitsbergen represent the remains of a preglacial surface.

Acknowledgements.-We want to thank Atle Mørk (IKU/ SINTEF) for data on parent rock and assistance in interpreting the XRD results, and Yoshihide Ohta (Norwegian Polar Institute) for information concerning gabbroid intrusives in the area. We also want to thank the University Centre in Svalbard for kindly lending us their geopenetrating radar. The fieldwork was funded by the Institute of Geosciences, Department of Physical Geography, University of Oslo, with additional financial support from the Norwegian Polar Institute. Laboratory work was carried out at the Institute of Geosciences. The modelling of preglacial landscape in the Isfjorden area, used for calculation of missing sediment volumes, was conducted by Bernd Etzelmüller. Constructive comments by Ole Humlum, Otto Salvigsen, Anders Elverhøi and two anonymous referees improved the manuscript and are much appreciated.

\section{References}

Ballantyne, C. K. \& Harris, C. 1994: The periglaciation of Britain. Cambridge, University Press.

Birks, H. H. 1991: Holocene vegetational history and climate change in west Spitsbergen - plant fossils from Skardtjørna. The Holocene 1, 209-218.

Büdel, J. 1982: Climatic geomorphology. Princeton, NJ: Princeton University Press.

Butt, F. A., Elverhøi, A., Solheim, A. \& Forsberg, C. F. 2000:
Deciphering Late Cenozoic development of the western Svalbard Margin from ODP Site 986 results. Mar. Geol. 169, 373-390.

Dallmann, W. K. 2002: Svalbard er som Norge for 10000 år siden. (Svalbard is like Norway was 10000 years ago.) On the Internet at www.forskning.no

Dallmann, W. K., Kjærnet, T. \& Nøttvedt, A. 2001: Geological map of Svalbard 1:100,000. C9G Adventdalen. Temakart 31/32. (Explanatory text.) Tromsø: Norwegian Polar Institute.

Dimakis, P., Braathen, B. I., Faleide, J. I., Elverhøi, A. \& Gudlaugsson, S. T. 1998: Cenozoic erosion and preglacial uplift of the Svalbard-Barents Sea region. Tectonophysics 300, 311-327.

Eiken, O. \& Austegard, A. 1987: The Tertiary belt of westSpitsbergen: seismic expressions of the offshore sedimentary basins. Nor. Geol. Tidsskr. 67, 383-394.

Elverhøi, A., Dowdeswell, J. A., Funder, S., Mangerud, J. \& Stein, R. 1998: Glacial and oceanic history of the polar North Atlantic margins: an overview. Quat. Sci. Rev. 17, $1-10$.

Elverhøi, A., Hooke, L. \& Solheim, A. 1998: Late Cenozoic sediment yield from the Svalbard-Barents sea region: implications for understanding erosion of glacierized basins. Quat. Sci. Rev. 17, 209-241.

Elverhøi, A., Svendsen, J. I., Solheim, A., Andersen, E. S., Milliman, J. \& Hooke, R. L. 1995: Late Quaternary sediment yield from the High Arctic Svalbard area. J. Geol. 103, 1-17.

Etzelmüller, B., Ødegård, R. S., Vatne, G., Mysterud, R. S., Tonning, T. \& Sollid, J. L. 2000: Glacier characteristic and sediment transfer systems of Longyearbyen and Larsbreen, western Spitsbergen. Nor. Geogr. Tidsskr. 54, 157-168.

Førland, E. J., Hanssen-Bauer, I. \& Nordli, P. Ø. 1997: Climate statistics and longterm series of temperature and precipitation at Svalbard and Jan Mayen. DNMI Klima Rapp. 21/97.

Forsberg, C. F., Solheim, A., Elverhøi, A., Jansen, E., Channell, J. E. T. \& Andersen, E. S. 1999: The depositional environment of the western Svalbard margin during the upper Pliocene and the Pleistocene; sedimentary facies changes at Site 986. In M. E. Raymo et al. (eds.): Proceedings of the Ocean Drilling Program, scientific results. Vol. 162, 233246. College Station, TX: Ocean Drilling Program.

Hagen, J. O., Liestøl, O., Roland, E. \& Jørgensen, T. 1993: Glacier atlas of Svalbard and Jan Mayen. Medd. 129. Oslo: Norwegian Polar Institute.

Hald, M. \& Dokken, T. 1995: Palaeoceanography on the European Arctic margin during the last deglaciation. Abstract. In J. T. Andrews et al. (eds.): The late glacial paleoceanography of the North Atlantic margins. Pp. 275-287. London: Geological Society.

Harland, W. B. 1969: Contribution of Spitsbergen to understanding of tectonic evolution of the North Atlantic region. In M. Kay (ed.): North Atlantic: geology and continental drift, a symposium, papers. Pp. 817-851. Tulsa, OK: American Association of Petrolium Geologists.

Harland, W. B. 1997: Neogene-Quaternary history. In W. B. Harland et al. (eds.): The geology of Svalbard. Pp. 418-435. London: The Geological Society.

Hjelle, A. 1993: Svalbards geologi. (Svalbard's geology.) Polarhåndb. 6. Oslo: Norwegian Polar Institute.

Hjelstuen, B. O., Elverhøi, A. \& Faleide, J. I. 1996: Cenozoic erosion and sediment yield in the drainage area of the Storfjorden Fan. Glob. Planet. Chang. 12, 95-117. 
Hjort, C., Mangerud, J., Adrielsson, L., Bondevik, S., Landvik, J. Y. \& Salvigsen, O. 1995: Radiocarbon dated common mussels Mytilus edulis from eastern Svalbard and the Holocene marine climatic optimum. Polar Res. 14, 239 243.

Houmark-Nielsen, M. \& Funder, S. 1999: Pleistocene stratigraphy of Kongsfjordhallet, Spitsbergen, Svalbard. Polar Res. 18, 39-49.

Hudec, P. P. 1973: Weathering of rocks in Arctic and subarctic environments. In J. D. Aitken \& D. J. Glass (eds.): Proceedings of the Symposium on the Geology of the Canadian Arctic. Pp. 313-335. Ottawa: Geological Association of Canada.

Humlum, O. 2002: Modelling late 20th-century precipitation in Nordenskiöld Land, Svalbard, by geomorphic means. Nor. J. Geogr. 56, 96-103.

Humlum, O., Instanes, A. \& Sollid, J. L. 2003: Permafrost in Svalbard: a review of research history, climatic background and engineering challenges. Polar Res. 22, 191-215.

Isaksen, K., Vonder Mühll, D., Gubler, H., Kohl, T. \& Sollid, J. L. 2000: Ground surface-temperature reconstruction based on data from a deep borehole in permafrost at Janssonhaugen, Svalbard. Ann. Glaciol. 31, 287-294.

Jeppesen, J. W. 2001: Palceoklimatiske indicatorer for central Spitsbergen, Svalbard. Eksemplificeret ved studier af iskiler og deres vertssedimenter. (Ice wedges and host sediments as palaeoclimatic indicators in central Spitsbergen, Svalbard). M. Sc. thesis, University Centre in Svalbard.

Landvik, J. Y., Bolstad, M., Lycke, A. K., Mangerud, J. \& Sejrup, H. P. 1992: Weichselian stratigraphy and palaeoenvironments at Bellsund, western Svalbard. Boreas 21, 335 358.

Landvik, J. Y., Bondevik, S., Elverhøi, A., Fjeldskaar, W., Mangerud, J., Salvigsen, O., Siegert, M. J., Svendsen, J. I. \& Vorren, T. O. 1998: The last glacial maximum of Svalbard and the Barents sea area: ice sheet extent and configuration. Quat. Sci. Rev. 17, 43-75.

Landvik, J. Y., Brook, E. J., Gualtieri, L., Raisbeck, G., Salvigsen, O. \& Yiou, F. 2003: Northwest Svalbard during the last glaciation: ice-free areas existed. Geology 31, 905-908.

Landvik, J. Y., Mangerud, J. \& Salvigsen, O. 1988: Glacial history and permafrost in the Svalbard area. Permafrost, Fifth International Conference, proceedings. Vol. 1. Pp. 194-198. Trondheim: Tapir Publishers.

Lehman, S. J. \& Forman, S. L. 1992: Late Weichselian glacier retreat in Kongsfjord, west Spitsbergen, Svalbard. Quat. Res. 37, 139-154.

Liestøl, O. 1977: Pingos, springs and permafrost in Spitsbergen. Nor. Polarinst. Arb. 1975, 7-29.

Major, H., Haremo, P., Dallmann, W. K. \& Andresen, A. 2000: Geological map of Svalbard. 1:100,000 sheet. C9G Adventdalen. Tromsø: Norwegian Polar Institute.

Mangerud, J., Bolstad, M., Elgersma, A., Helliksen, D., Landvik, J. Y., Lønne, I., Lycke, A. K., Salvigsen, O., Sandahl, T. \& Svendsen, J. I. 1992: The last glacial maximum on Spitsbergen, Svalbard. Quat. Res. 38, 1-31.

Mangerud, J., Jansen, E. \& Landvik, J. Y. 1996: Late Cenozoic history of the Scandinavian and Barents Sea ice sheets. Glob. Planet. Chang. 12, 11-26.

Manum, S. B. \& Throndsen, T. 1978: Rank of coal and dispersed organic matter in its geological bearing in the Spitsbergen Tertiary. Nor. Polarinst. Arb. 1977, 159-177.

Miller, G. H. 1982: Quaternery depositional episodes, western Spitsbergen, Norway: aminostratigraphy and glacial history. Arct. Alp. Res. 14, 321-340.
Miller, G. H., Sejrup, H. P., Lehman, S. J. \& Forman, S. L. 1989: Glacial history and marine environmental change during the last interglacial-glacial cycle, western Spitsbergen, Svalbard. Boreas 18, 273-296.

Miloslavskij, M. J., Birjukov, A. S., Slënskij, S. N., Hansen, S., Larsen, B. T., Dallmann, W. K. \& Andresen, A. 1992: Geological map of Svalbard. 1:100,000. Sheet D9G, Agardhfjellet. Oslo: Norwegian Polar Institute.

Miloslavskij, M. J., Birjukov, A. S., Slënskij, S. N., Krasil’šcikov, A. A. \& Dallmann, W. K. 1996: Geological map of Svalbard. 1:100.000. Sheet D8G, Negribreen. Oslo: Norwegian Polar Institute.

Mørk, A. \& Bjorøy, M. 1984: Mesozoic source rocks on Svalbard. In A. M. Spencer et al. (eds.): Petroleum geology of the North European Margin. Pp. 371-382. London: Norwegian Petroleum Society, Graham \& Trotman.

Salvigsen, O., Adrielsson, L., Hjort, C., Kelley, M., Landvik, J. Y. \& Ronnert, L. 1995: Dynamics of the last glaciation in eastern Svalbard as inferred from glacier-movement indicators. Polar Res. 14, 141-152.

Salvigsen, O., Forman, S. \& Miller, G. H. 1992: Thermophilous molluscs on Svalbard during the Holocene and their paleoclimatic implications. Polar Res. 11, 1-10.

Salvigsen, O. \& Mangerud, J. 1991: Holocene shoreline displacement at Agardhbukta, eastern Spitsbergen, Svalbard. Polar Res. 9, 1-7.

Sandberg, S. 2004: Fant blåskjell i Isfjorden. (Mussels found in Isfjorden.) Svalbardposten 17 Sept., 8-9.

Smelror, M. 1999: Pliocene-Pleistocene and redeposited dinoflagellate cysts from the western Svalbard margin (Site 986): biostratigraphy, palaeoenvironments and sediment provenance. In M. E. Raymo et al. (eds.): Proceedings of the Ocean Drilling Program, scientific results. Vol. 162. Pp. 83-97. College Station, TX: Ocean Drilling Program.

Sollid, J. L., Andersen, S., Hamre, N., Kjeldsen, O., Salvigsen, O., Sturød, S., Tveitå, T. \& Wilhelmsen, A. 1973: Deglaciation of Finnmark, north Norway. Nor. Geogr. Tidsskr. 27, 233-325 (and map).

Sollid, J. L. \& Sørbel, L. 1988a: Utbredelsesmønstret av løsmateriale og landformer på Svalbard-noen hovedtrekk. (Distribution of superficial materials and landforms in Svalbard-some main features.) Nor. Geogr. Tidsskr. 42, 265-270.

Sollid, J. L. \& Sørbel, L. 1988b: Influence of temperature conditions in formation of end moraines in Fennoscandia and Svalbard. Boreas 17, 553-558.

Sørbel, L. \& Tolgensbakk, J. 2002: Ice-wedge polygons and solifluction in the Adventdalen area, Spitsbergen, Svalbard. Nor. J. Geogr. 56, 62-66.

Sørbel, L., Tolgensbakk, J., Hagen, J. O. \& Høgvard, K. 2001: Geomorphological and Quaternary geological map of Svalbard 1:100,000. C9Gq Adventdalen. (Explanatory text.) Temakart 31/32. Tromsø: Norwegian Polar Institute.

Steel, R., Gjelberg, J., Helland-Hansen, W., Kleinspehn, K., Nøttvedt, A. \& Rye Larsen, M. 1985: The Tertiary strike slip basins and orogenic belt of Spitsbergen. In K. T. Biddle \& N. Christie-Blick (eds.): Strike-slip deformation, basin formation, and sedimentation. Pp. 339-359. Tulsa, OK: Society of Economic Paleontologists and Mineralogists.

Svensson, H. 1962: Note of a type of patterned ground on the Varanger peninsula, Norway. Geogr. Ann. 44, 413.

Thoresen, M. K. 1990: Kvartcergeologisk kart over Norge. Tema: jordarter. (Quaternary map of Norway. Topic: soil types.) Trondheim: Norwegian Geological Survey.

Tolgensbakk, J., Sørbel, L. \& Høgvard, K. 2001: Geomor- 
phological and Quaternary geological map of Svalbard 1:100,000. C9Gq Adventdalen. Temakart 31/32. Tromsø: Norwegian Polar Institute.

Vorren, T. O., Hald, M. \& Lebesbye, E. 1988: Late Cenozoic environments in the Barents Sea. Palaeoceanography 3, 601-612.

Vorren, TO. O., Richardsen, G., Knutsen, S.-M. \& Henriksen, E. 1991: Cenozoic erosion and sedimentation in the western
Barents Sea. Mar. Pet. Geol. 8, 317-340.

Washburn, A. L. 1979: Geocryology: a survey of periglacial processes and environments. London: Edward Arnold.

Weslawski, J. M., Zajackowski, M., Wiktor, J. \& Szymelfenig, M. 1997: Intertidal zone of Svalbard. 3. Littoral of a subarctic, oceanic island: Bjørnøya. Polar Biol. 15, 45-52.

White, S. E. 1976: Is frost action really only hydration shattering? Arct. Alp. Res. 8, 1-6. 
